\title{
Hemato-biochemical and oxidative effect of fresh juice and ethanolic extract of Ficus tsiela Roxb in rats
}

\author{
Litty Mathew ${ }^{1}$, N. Divakaran Nair ${ }^{1}$, N. Vijayan ${ }^{1}$ and K. A. Mercey² \\ 1. Department of Pathology, College of Veterinary and Animal Sciences, Mannuthy, Kerala, India; 2. Department of \\ Statistics, College of Veterinary and Animal Sciences, Mannuthy, Kerala, India. \\ Corresponding author: Litty Mathew, e-mail: drlittymathew@gmail.com, NDN: divakaran@kvasu.ac.in, \\ NV: vijayan@kvasu.ac.in, KAM: mercey@kvasu.ac.in \\ Received: 05-07-2014, Revised: 20-09-2014, Accepted: 23-09-2014, Published online: 31-10-2014
}

doi: 10.14202/vetworld.2014.890-894. How to cite this article: Mathew L, Nair ND, Vijayan N, Mercey KA (2014) Hemato-biochemical and oxidative effect of fresh juice and ethanolic extract of Ficus tsiela Roxb in rats, Veterinary World 7(10): 890-894.

\begin{abstract}
Aim: The goal was to assess the hemato-biochemical and oxidative changes of Ficus tsiela Roxb in rats.

Materials and Methods: A total of 48 adult female Sprague-Dawley rats weighing 200-250 g were divided into six groups with eight rats in each group. Group 1 received no treatment served as a control group. Group 2 and 3 animals were orally ingested with fresh juice from $5 \mathrm{~g}$ of leaves and $10 \mathrm{~g}$ of leaves, respectively. Group 4, 5 and 6 animals were orally administered with the extract at doses of 750,1000 and $1500 \mathrm{mg} / \mathrm{kg}$, respectively. The experiment was continued for a period of 21 days. Biochemical parameters including aspartate aminotransferase (AST), alkaline phosphatase (ALP), creatinine kinase (CK), creatinine and blood glucose and hematological parameters such as hemoglobin (Hb), packed cell volume (PCV), total leukocyte count (TLC) and differential leucocyte count (DLC) were determined on 0, 7, 14, and 21 day of treatment. Lipid peroxides and reduced glutathione values were determined in liver at day 21.
\end{abstract}

Results: Hb, PCV, TLC and DLC showed no significant variations in treated groups compared with control and ALP, AST, CK and creatinine values showed a significant increase in serum of the higher dose groups. There was no variation in the level of blood sugar. There was an increase in the values of lipid peroxides and reduction in the values of reduced glutathione in the liver homogenate which indicated oxidative damage.

Conclusion: The fresh juice and ethanolic extract at higher doses had no effect on hematological values. However, biochemical parameters affected adversely. Both fresh juice and extract caused oxidative damage to liver.

Keywords: biochemical, Ficus tsiela, phytotoxicity.

\section{I ntroduction}

Ficus tsiela is one of the common toxic plants in Kerala and is known as Chela or Chelakkoli, belongs to the family Moraceae and genus Ficus. Ficus is a large and varied genus and comprises about 800 species. The plant is distributed widely throughout the warmer parts of Asia, Africa, America and Australia. In India, it is common in the Western Ghats. F. tsiela plant has been listed as poisonous one in the International Poisonous Plants Checklist [1]. Both natural and experimental toxicities of the plant leaves have been reported [2,3]. During the seasons of scarcity or due to ignorance, farmers may feed their cattle with the tree leaves, and they show symptoms of toxicity.

Reports are available about the medicinal value of the plant in traditional medicine [4]. In some part of Kerala, bark and leaves of the plant are used for chewing along with lime and betel leaves. No antimicrobial activity was observed with the aqueous extract of the plant, although high activity was exhibited with the ethanolic, moderate activity with methanolic and

Copyright: The authors. This article is an open access article licensed under the terms of the Creative Commons Attributin License (http:// creative commons.org/licenses/by/2.0) which permits unrestricted use, distribution and reproduction in any medium, provided the work is properly cited. mild activity with chloroform extract [4]. The Gramnegative bacteria appeared to be more susceptible to the antimicrobial effect of the extracts than the Grampositive organisms. Extensive investigation has been carried out on the digestibility, and nutritive value of F. tsiela [5].

F. tsiela is a plant whose toxicological properties have not been extensively studied. The traditional uses on human beings and its indication as a poisonous plant in livestock, especially in cattle, make it an interesting candidate for phytochemical analysis and further toxicological studies. For every experiment conducted, the susceptible animal is the most suitable model. But often it is not possible because of the stringent restrictions imposed by animal ethics committee. Therefore, the accepted suitable alternative is to assess the effect in the laboratory animals. But no sufficient data are available regarding the toxicity of F. tsiela in laboratory animals except the behavior of male rats treated with extracts of $F$. tsiela [6]. Therefore, it is envisaged to study the effect of fresh juice and alcoholic extract and its toxic principles in suitable laboratory animal models to develop antidotes.

Therefore the present study was conducted to observe the toxic effects of $F$. tsiela fresh juice and alcoholic extracts in hemato-biochemical and oxidative parameters in rats and assessing the suitability of 
rat as a laboratory animal model for expressing all the established toxicities.

\section{Materials and Methods \\ Ethical approval}

The study protocol followed the ethical guidelines on the proper care and use of animals and had been approved by the Institutional Animal Ethics Committee.

\section{Plant materials}

Leaves and tender stem of the plant $F$. tsiela Roxb were collected from the campus of College of Veterinary and Animal Sciences, Mannuthy and identity confirmed. These materials were washed in running water, air-dried, coarsely pulverized and then extracted using a Soxhlet apparatus with 95\% ethanol. The ethanolic extract was concentrated in a rotary vacuum evaporator under reduced pressure, and temperature $\left(55^{\circ} \mathrm{C}\right)$ and kept under refrigeration for the complete evaporation of the solvent. The extract was administered orally to the experimental animals. The fresh juice was prepared by the maceration of weighed quantity of leaves along with the latex. The leaves were weighed and macerated with water using mortar and pestle and solution was filtered, and the filtrate was given orally. The ethanolic extract and fresh juice obtained from the leaves of F. tsiela Roxb was tested for the presence of various active principles namely steroids, alkaloids, tannins, phenolic compounds, flavonoids, glycosides, diterpenes, triterpenes and saponins as per the procedure quoted by Harborne [7].

\section{Animals}

Forty-eight adult female Sprague Dawley rats weighing 200-250 g were obtained from Small Animal Breeding Station, College of Veterinary and Animal Sciences, Mannuthy. All animals had free access to water and food, except for a short fasting period before oral administration of single doses of the plant extract or fresh juice.

\section{Experimental design}

The animals were randomly divided into six groups of eight animals each and their baseline hematological and biochemical values were determined. Group 1 receiving no treatment served as the control group. Group 2 and 3 animals were orally ingested with fresh juice from $5 \mathrm{~g}$ leaves and $10 \mathrm{~g}$ leaves respectively. The extract was ingested orally at doses of 750,1000 and $1500 \mathrm{mg} / \mathrm{kg}$ body weight to Group 4, 5 and 6 , respectively.

\section{Estimation of hemato-biochemical and oxidative parameters}

Blood was collected from the retro-orbital plexus under mild ether anesthesia with capillary tubes into fresh vials with ethylene diamine tetraacetic acid (EDTA) as anticoagulant at the rate of $2 \mathrm{mg} / \mathrm{ml}$ for estimation of hemoglobin ( $\mathrm{Hb})$, total leukocyte count (TLC), packed cell volume (PCV) and differential leukocyte count (DLC) [8,9]. The blood smears were fixed with methanol for 5 min and stained with Giemsa's stain (1:10 dilution) for 25 min and observed under oil immersion lens for DLC. Serum was used for the estimation of aspartate aminotransferase (AST), alkaline phosphatase (ALP), creatinine kinase (CK), creatinine and blood glucose. AST and ALP were estimated by using Ecoline ${ }^{\circledR}$ kit (M/s. E. Merck India Limited, Mumbai). CPK estimation was done by using CK (S.L) kit (M/s. Agappe Diagnostics, Ernakulam). Creatinine was estimated by using Mekotest ${ }^{\circledR}$ kit (M/s. E. Merck India Limited, Mumbai). Blood glucose was estimated by using NICE diagnostic kit (Nice Chemicals Pvt. Ltd., Cochin). Hemato-biochemical examination was done on day $0,7,14$ and 21 . At the end of 21 day, animals were sacrificed and liver was collected and then washed in running tap water to remove the blood clots and weighed amount of tissue was kept in chilled normal saline for estimation of lipid peroxides and reduced glutathione. For the estimation of lipid peroxides, $0.5 \mathrm{~g}$ of freshly excised liver tissue was homogenized with $5 \mathrm{ml}$ Tris - $\mathrm{HCl}$ buffer ( $\mathrm{pH}$ 7.5). For the estimation of reduced glutathione, homogenate of liver was prepared in the ratio of $0.5 \mathrm{~g}$ of wet tissue to $4 \mathrm{ml}$ of phosphate buffer and then centrifuged at $5000 \mathrm{rpm}$, and the supernatant was used. Levels of reduced glutathione and lipid peroxides of liver homogenate were estimated by standard procedures [10,11].

\section{Statistical analysis}

Data were collected from various biochemical parameters were analysed as per the method of Snedecor and Cochran [12] by using one-way analysis of variance (ANOVA) followed by Duncans multiple range test for grouping means having significance.

\section{Results}

Phytochemical analysis of the fresh juice revealed the presence of tannins, glycosides, diterpenes, triterpenes, alkaloids, flavonoids and phenolic compounds whereas the alcoholic extract revealed the presence of tannins, phenolic compounds, diterpenes and triterpenes.

The parameters such as Hb, PCV, TLC and DLC, as well as blood glucose, showed no significant variations in treated groups compared with control group. The hematological observations are summarized in Table-1.

The biochemical observations are summarized in Table-2. On day 7, the mean AST levels showed a significant increase at $(\mathrm{p}<0.05)$ in Group 5 and 6 when compared to the control group. On day 14, Group 5 and 6 values showed a significant increase at $(\mathrm{p}<0.01)$ and Group 3 values showed a significant increase at $5 \%$ level when compared with control. On day 21, Group 3, 5 and 6 showed significant $(p<0.01)$ increase compared to control the group. Levels of ALP showed no significant variations on day 0 and 7 . But on day 14 and 21, Group 3, 5 and 6 showed significant $(\mathrm{p}<0.01)$ 
Table-1: Effect of F. tsiela Rox b extract and fresh juice on various haematological parameters in adult female Sprague Dawley rats.

\begin{tabular}{|c|c|c|c|c|c|}
\hline \multirow[t]{2}{*}{ Parameters } & \multirow[t]{2}{*}{ Groups } & \multicolumn{4}{|c|}{ I ntervals } \\
\hline & & Day 0 & Day 7 & Day 14 & Day 21 \\
\hline \multirow[t]{6}{*}{ Mean $\mathrm{Hb}$ concentration ( $\mathrm{g} / \mathrm{dl}$ ) } & G1 & $14.85^{\mathrm{a}} \pm 0.16$ & $14.61^{\mathrm{a}} \pm 0.96$ & $14.50^{\mathrm{a}} \pm 0.01$ & $14.1^{\mathrm{a}} \pm 0.01$ \\
\hline & $\mathrm{G} 2$ & $14.48^{\mathrm{a}} \pm 0.12$ & $14.38^{\mathrm{a}} \pm 0.94$ & $14.30^{\mathrm{a}} \pm 0.08$ & $14.32^{\mathrm{a}} \pm 0.08$ \\
\hline & G3 & $14.92^{\mathrm{a}} \pm 0.18$ & $14.542^{\mathrm{a}} \pm 0.01$ & $14.38^{\mathrm{a}} \pm 0.08$ & $14.69^{\mathrm{a}} \pm 0.07$ \\
\hline & G4 & $14.69^{\mathrm{a}} \pm 0.22$ & $14.521^{\mathrm{a}} \pm 0.94$ & $14.54^{\mathrm{a}} \pm 0.08$ & $14.55^{\mathrm{a}} \pm 0.08$ \\
\hline & G5 & $14.51^{\mathrm{a}} \pm 0.22$ & $14.41^{\mathrm{a}} \pm 0.12$ & $14.42^{\mathrm{a}} \pm 0.08$ & $14.32^{\mathrm{a}} \pm 0.04$ \\
\hline & G6 & $14.35^{\mathrm{a}} \pm 0.28$ & $14.133^{\mathrm{a}} \pm 0.95$ & $14.34^{\mathrm{a}} \pm 0.08$ & $14.3^{\mathrm{a}} \pm 0.28$ \\
\hline \multirow[t]{6}{*}{ Mean PCV (\%) } & G1 & $42.50^{\mathrm{a}} \pm 0.27$ & $42.00^{\mathrm{a}} \pm 0.27$ & $42.38^{a} \pm 0.18$ & $41.63^{\mathrm{a}} \pm 0.42$ \\
\hline & $\mathrm{G} 2$ & $40.63^{a} \pm 0.56$ & $40.63^{\mathrm{a}} \pm 0.37$ & $40.63^{a} \pm 0.42$ & $40.63^{a} \pm 0.37$ \\
\hline & G3 & $42.13^{\mathrm{a}} \pm 0.64$ & $41.63^{\mathrm{a}} \pm 0.53$ & $40.88^{a} \pm 0.72$ & $40.63^{a} \pm 0.63$ \\
\hline & G4 & $40.50^{a} \pm 0.98$ & $40.25^{\mathrm{a}} \pm 0.70$ & $40.13^{a} \pm 0.64$ & $40.00^{a} \pm 0.57$ \\
\hline & G5 & $40.63^{a} \pm 0.73$ & $40.13^{a} \pm 0.87$ & $40.50^{a} \pm 0.71$ & $40.25^{a} \pm 0.75$ \\
\hline & G6 & $41.63^{\mathrm{a}} \pm 0.98$ & $40.50^{a} \pm 0.76$ & $40.88^{a} \pm 0.87$ & $39.63^{a} \pm 0.68$ \\
\hline \multirow[t]{6}{*}{ Mean TLC (thousands per $\mathrm{mm}^{3}$ ) } & G1 & $7.51^{\mathrm{a}} \pm 1.89$ & $7.45^{\mathrm{a}} \pm 1.13$ & $7.45^{\mathrm{a}} \pm 1.12$ & $7.48^{\mathrm{a}} \pm 1.17$ \\
\hline & $\mathrm{G} 2$ & $7.43^{\mathrm{a}} \pm 1.59$ & $7.44^{\mathrm{a}} \pm 1.02$ & $7.38^{\mathrm{a}} \pm 1.12$ & $7.52^{\mathrm{a}} \pm 1.19$ \\
\hline & G3 & $7.46^{\mathrm{a}} \pm 1.19$ & $7.48^{\mathrm{a}} \pm 1.82$ & $7.53^{\mathrm{a}} \pm 1.12$ & $7.51^{\mathrm{a}} \pm 1.11$ \\
\hline & G4 & $7.42^{\mathrm{a}} \pm 1.62$ & $7.41^{\mathrm{a}} \pm 1.34$ & $7.43^{\mathrm{a}} \pm 1.11$ & $7.48^{\mathrm{a}} \pm 1.59$ \\
\hline & G5 & $7.44^{\mathrm{a}} \pm 1.59$ & $7.56^{\mathrm{a}} \pm 1.76$ & $7.56^{\mathrm{a}} \pm 1.76$ & $7.50^{\mathrm{a}} \pm 1.19$ \\
\hline & G6 & $7.49^{\mathrm{a}} \pm 1.12$ & $7.44^{\mathrm{a}} \pm 1.10$ & $7.39^{\mathrm{a}} \pm 1.12$ & $7.39^{\mathrm{a}} \pm 1.14$ \\
\hline \multirow{6}{*}{ Mean blood glucose $(\mathrm{mg} / \mathrm{dl})$} & G1 & $82.18^{\mathrm{a}} \pm 2.29$ & $80.79^{a} \pm 1.53$ & $81.23^{a} \pm 2.33$ & $83.09^{a} \pm 1.51$ \\
\hline & $\mathrm{G} 2$ & $82.85^{\mathrm{a}} \pm 2.09$ & $83.01^{\mathrm{a}} \pm 1.45$ & $82.08^{\mathrm{a}} \pm 2.99$ & $82.96^{\mathrm{a}} \pm 2.85$ \\
\hline & G3 & $81.21^{\mathrm{a}} \pm 2.04$ & $79.08^{\mathrm{a}} \pm 2.18$ & $78.72^{\mathrm{a}} \pm 1.89$ & $77.08^{\mathrm{a}} \pm 1.62$ \\
\hline & G4 & $81.43^{\mathrm{a}} \pm 2.13$ & $81.58^{a} \pm 1.91$ & $81.45^{\mathrm{a}} \pm 2.25$ & $78.31^{\mathrm{a}} \pm 1.98$ \\
\hline & G5 & $83.01^{\mathrm{a}} \pm 2.45$ & $80.99^{a} \pm 2.01$ & $80.15^{\mathrm{a}} \pm 2.49$ & $81.49^{a} \pm 2.58$ \\
\hline & G6 & $82.99^{a} \pm 2.28$ & $81.30^{\mathrm{a}} \pm 1.98$ & $80.40^{\mathrm{a}} \pm 1.60$ & $79.13^{\mathrm{a}} \pm 1.47$ \\
\hline
\end{tabular}

Means bearing same superscript in the same column does not differ significantly, F. tsiela=Ficus tsiela, Hb=Hemoglobin, PCV=Packed cell volume, TLC=Total leukocyte count

Table-2: Effect of F. tsiela Rox b extract and fresh juice on various biochemical parameters in adult female Sprague Dawley rats.

\begin{tabular}{|c|c|c|c|c|c|}
\hline \multirow[t]{2}{*}{ Parameters } & \multirow[t]{2}{*}{ Groups } & \multicolumn{4}{|c|}{ I ntervals } \\
\hline & & Day 0 & Day 7 & Day 14 & Day 21 \\
\hline \multirow[t]{6}{*}{$\overline{A S T}(I U / L)$} & G1 & $144.88^{a} \pm 2.34$ & $144^{\mathrm{Aa}} \pm 2.46$ & $143.13^{\mathrm{Aa}} \pm 3.00$ & $143.75^{\mathrm{Aa}} \pm 1.96$ \\
\hline & $\mathrm{G} 2$ & $145.88^{\mathrm{a}} \pm 3.19$ & $145.13^{\mathrm{Aa}} \pm 3.06$ & $146.88^{\mathrm{Aa}} \pm 3.91$ & $148.38^{\mathrm{Aa}} \pm 3.83$ \\
\hline & G3 & $144.13^{\mathrm{a}} \pm 2.21$ & $146.50^{\mathrm{Aa}} \pm 2.62$ & $153.38^{\mathrm{Ab}} \pm 1.89$ & $167.38^{\complement} \pm 4.11$ \\
\hline & $\mathrm{G} 4$ & $144.63^{\mathrm{a}} \pm 3.59$ & $147.0^{\mathrm{Aa}} \pm 3.19$ & $146.50^{\mathrm{Aa}} \pm 3.65$ & $149.88^{\mathrm{Aa}} \pm 4.25$ \\
\hline & G5 & $145.63^{\mathrm{a}} \pm 3.60$ & $155.38^{\mathrm{Ba}} \pm 1.50$ & $178.00^{\mathrm{BC}} \pm 2.49$ & $221.75^{D} \pm 5.63$ \\
\hline & G6 & $145.63^{a} \pm 1.93$ & $180.63^{\mathrm{ca}} \pm 3.59$ & $183.63^{B C} \pm 3.53$ & $243.5 E \pm 9.63$ \\
\hline \multirow[t]{6}{*}{ ALP (IU/L) } & G1 & $635.88^{a} \pm 8.98$ & $632.38^{a} \pm 8.76$ & $633.88^{\mathrm{Aa}} \pm 9.28$ & $634.25^{\mathrm{a}} \pm 5.73$ \\
\hline & $\mathrm{G} 2$ & $635.63^{\mathrm{a}} \pm 9.23$ & $637.63^{\mathrm{a}} \pm 9.40$ & $637.25^{\mathrm{Aa}} \pm 7.76$ & $639.63^{a} \pm 7.03$ \\
\hline & G3 & $633.88^{a} \pm 8.75$ & $632.63^{\mathrm{a}} \pm 8.54$ & $656.63^{\mathrm{B}} \pm 17.63$ & $668.0^{B} \pm 22.52$ \\
\hline & G4 & $633.13^{\mathrm{a}} \pm 8.11$ & $633.63^{\mathrm{a}} \pm 8.46$ & $635.5^{\mathrm{Aa}} \pm 9.69$ & $631.5^{\mathrm{a}} \pm 7.65$ \\
\hline & G5 & $639.0^{\mathrm{a}} \pm 10.47$ & $639.88^{\mathrm{a}} \pm 8.85$ & $674.0^{C} \pm 14.5$ & $723.0^{c} \pm 27.13$ \\
\hline & G6 & $640.63^{\mathrm{a}} \pm 8.43$ & $643.75^{\mathrm{a}} \pm 8.95$ & $675.75^{D} \pm 13.91$ & $737.38^{\mathrm{D}} \pm 40.38$ \\
\hline \multirow[t]{6}{*}{ CK (IU/L) } & G1 & $324^{\mathrm{a}} \pm 7.38$ & $324.75^{\mathrm{a}} \pm 8.75$ & $322.88^{a} \pm 9.58$ & $326.88^{\mathrm{Aab}} \pm 8.70$ \\
\hline & $\mathrm{G} 2$ & $324.75^{\mathrm{a}} \pm 8.58$ & $324.63^{\mathrm{a}} \pm 8.93$ & $327.25^{\mathrm{a}} \pm 5.90$ & $326.13^{\mathrm{Aab}} \pm 8.78$ \\
\hline & G3 & $326.13^{\mathrm{a}} \pm 5.96$ & $326.38^{a} \pm 6.32$ & $332.63^{a} \pm 6.63$ & $336.75^{\mathrm{Aab}} \pm 8.36$ \\
\hline & G4 & $324.88^{\mathrm{a}} \pm 8.01$ & $325.25^{\mathrm{a}} \pm 7.72$ & $326.25^{\mathrm{a}} \pm 6.71$ & $326.63^{\mathrm{Aab}} \pm 8.01$ \\
\hline & G5 & $327.50^{\mathrm{a}} \pm 7.95$ & $331.25^{\mathrm{a}} \pm 7.21$ & $335.00^{a} \pm 8.55$ & $341.63^{\mathrm{Aab}} \pm 9.37$ \\
\hline & G6 & $323.25^{\mathrm{a}} \pm 6.52$ & $327.13^{\mathrm{a}} \pm 5.79$ & $339.75^{\mathrm{a}} \pm 7.07$ & $369.25^{\mathrm{Bc}} \pm 14.51$ \\
\hline \multirow[t]{6}{*}{ Serum creatinine $(\mathrm{mg} / \mathrm{dl})$} & G1 & $0.475^{\mathrm{a}} \pm 0.001$ & $0.500^{\mathrm{a}} \pm 0.000$ & $0.488^{\mathrm{Aa}} \pm 0.001$ & $0.488^{\mathrm{Aa}} \pm 0.002$ \\
\hline & $\mathrm{G} 2$ & $0.488^{a} \pm 0.001$ & $0.488^{a} \pm 0.001$ & $0.500^{\mathrm{Aa}} \pm 0.000$ & $0.513^{\mathrm{Aa}} \pm 0.002$ \\
\hline & G3 & $0.475^{\mathrm{a}} \pm 0.001$ & $0.513^{\mathrm{a}} \pm 0.002$ & $0.500^{\mathrm{Aa}} \pm 0.000$ & $0.563^{\mathrm{B}} \pm 0.002$ \\
\hline & G4 & $0.500^{\mathrm{a}} \pm 0.000$ & $0.500^{\mathrm{a}} \pm 0.001$ & $0.500^{\mathrm{Aa}} \pm 0.000$ & $0.612^{\mathrm{B}} \pm 0.002$ \\
\hline & G5 & $0.462^{\mathrm{a}} \pm 0.001$ & $0.650^{\mathrm{B}} \pm 0.001$ & $0.550^{\mathrm{Bb}} \pm 0.001$ & $0.612^{\mathrm{B}} \pm 0.002$ \\
\hline & G6 & $0.500^{\mathrm{a}} \pm 0.000$ & $0.688^{\mathrm{B}} \pm 0.001$ & $0.600^{\mathrm{BC}} \pm 0.002$ & $0.650^{C} \pm 0.001$ \\
\hline
\end{tabular}

Means bearing same superscript in the same column does not differ significantly: $A, B, C, D, E-P<0.01$ significance; $a, b, c-P<0.05$ significance. AST=Aspartate aminotransferase, ALP=Alkaline phosphatase, $C K=C r e a t i n e ~ k i n a s e$,

F. tsiela $=$ Ficus tsiela

increase when compared to control. Significant variations were not observed in the levels of CK on day 0 , 7 and 14 but on $21^{\text {st }}$ day, the mean value of the sixth group was increased significantly $(\mathrm{p}>0.05)$ when compared to control group. On day 7 and 14, statistically significant increase in mean creatinine values 
was observed in Group 5 and 6 when compared to control group at $(\mathrm{p}<0.01)$. On day 21 , statistically significant increase $(p<0.01)$ was observed in Group 3, 4 in addition to Groups 5 and 6 when compared to control group.

A significant increase in the level of lipid peroxides was observed in the liver of Group 3 and 6 when compared to the control group (Table-3). Group 6 (highest dose - $1500 \mathrm{mg} / \mathrm{kg}$ body weight) showed statistically significant decrease in mean values $(p<0.01)$ of reduced glutathione when compared to control group.

\section{Discussion}

Phytochemical screening of crude extracts of leaves of F. tsiela using chemical method was done earlier which revealed the presence of many bioactive constituents and they reported the absence of alkaloid in ethanolic, methanolic and chloroform extract [4]. In the present study also, alkaloid was absent in the ethanolic extract, but it was present in the fresh juice.

Absence of significant variation in hematological parameters indicated that both the extract and fresh juice from leaves of $F$. tsiela have no adverse effect on the hemopoietic system at the given doses. The non-toxic nature of aqueous leaf extracts of Ficus exasperate was established earlier based on its effects on hematological parameters (white blood cell count, platelet and hemoglobin), body weight and temperature [13]. However in the present study, the findings may attribute to the species variation rather than the non-toxic nature of the plant. Earlier reports showed that ad libitum feeding of this plant in calves produced symptoms of neurotoxicity whereas in goats, it did not produce much effect [14]. No significant change could be observed in the blood glucose of the treated groups when compared with the control group. However in calves, transient hypoglycaemia was observed in experimentally induced F. tsiela toxicity [3]. This may again indicate species variation in the response of the organs to toxicity.

The activity of the enzyme AST is high in liver and hence hepatic injury causes high AST activity

Table-3: Mean values of lipid peroxides ( $\mathrm{nMol}$ of malondialdehyde/g of wet tissue) and reduced glutathione $(\mu \mathrm{g} / \mathrm{g}$ of wet tissue) of rats administered with fresh juice and ethanolic extract of F. tsiela Roxb.

\begin{tabular}{lcc}
\hline Group & $\begin{array}{c}\text { Lipid peroxides } \\
\text { (nMol of malondialdehyde/ } \\
\text { g of wet tissue) }\end{array}$ & $\begin{array}{c}\text { Reduced } \\
\text { glutathione }(\boldsymbol{\mu g} / \\
\text { g of wet tissue) }\end{array}$ \\
\hline $\mathrm{G} 1$ & $314.38^{\mathrm{Aa}} \pm 15.48$ & $523.75^{\mathrm{A}} \pm 13.75$ \\
$\mathrm{G} 2$ & $324.38^{\mathrm{Aa}} \pm 14.31$ & $526.88^{\mathrm{A}} \pm 10.85$ \\
$\mathrm{G} 3$ & $388.13^{\mathrm{B}} \pm 17.16$ & $482.50^{\mathrm{Ba}} \pm 9.96$ \\
$\mathrm{G} 4$ & $319.63^{\mathrm{Aa}} \pm 13.67$ & $519.38^{\mathrm{AB}} \pm 10.15$ \\
$\mathrm{G} 5$ & $346.88^{\mathrm{Ab}} \pm 8.81$ & $441.25^{\mathrm{Bb}} \pm 15.86$ \\
$\mathrm{G} 6$ & $416.88^{\mathrm{B}} \pm 22.77$ & $381.25^{\mathrm{C}} \pm 20.39$ \\
\hline
\end{tabular}

Means bearing same superscript in the same column does not differ significantly $A, B,-p<0.01$ significance; $\mathrm{a}, \mathrm{b}-\mathrm{p}<0.05$ significance. $\mathrm{F}$. tsiela $=$ Ficus tsiela in serum. AST activity is also high in kidney, pancreas and in erythrocytes. The increase in activity of the enzymes in the plasma is often seen following liver damage, and it is attributed to the leakage of the enzymes from damaged hepatocytes [15]. High levels of AST also indicate cardiac infarction and muscle injury [16]. The significant increase in ALP could be attributed to the damage to the liver, kidney and intestine [15]. A small increase in serum CK and marked the rise in AST serve as an indicator of muscle ischemia incident or surgery $[15,17]$. Serum CK activity is a more sensitive indicator in early stage of myocardial ischemia [18]. The group of rats which were fed with high doses of the extract showed an increase in CK value on 21st day due to the cardiac myopathy caused by the toxins. There are reports that correlate vital organ damage and significant elevation of enzymes like AST $[3,19]$, AST and creatinine $[20,21]$ etc. Increase in activity of serum AST and ALP and concurrent histopathological lesions in kidney and liver were reported earlier in calves in experimental F. tsiela toxicity [22]. So in the present study, the biochemical alterations could be largely attributed to its pathological effects on vital organs.

Oxidative effect of the plant juice and extract on liver was determined by measuring the alterations in the values of lipid peroxides and reduced glutathione in liver homogenates. Oxidation of lipid molecules of biological membrane causes membrane damage resulting in the development of the several pathological disorders [23]. On the other hand, glutathione is an important antioxidant, which functions as free radical scavenger. Decreased functional reduced glutathione levels have been considered to be an indicator of oxidative stress. In this study, it was observed that both the extract and fresh juice of F. tsiela could cause oxidative damage as there was a statistically significant increase in lipid peroxides and a concurrent decrease in reduced glutathione. Phenolic compounds from plants possess the ability to absorb and neutralize free radicals [24]. Similarly, flavonoids present in most plants also exhibit in vitro and in vivo antioxidant activity [25], but in the present study, the flavonoids, diterpenes and phenolic compounds could not resist the damage probably because of the higher concentrations of the toxic principles. Significant increase in lipid peroxides and a concurrent decrease in reduced glutathione were reported by earlier workers in toxicity with different plants [26,27].

\section{Conclusion}

From this study, it was concluded that the extract and fresh juice at higher concentration can cause changes in biochemical parameters and cause oxidative damage to the liver. But even at higher concentration, the extract and fresh juice had no effect on hematological parameters. 


\section{Authors' Contributions}

LM and NDN have designed a plan of work. LM carried out the laboratory work. NDN and NV supervised the research. KAM helped with the statistical analysis. LM drafted and revised the manuscript. All authors read and approved the final manuscript.

\section{Acknowledgments}

The authors are thankful to the Dean, College of Veterinary and Animal Sciences, Mannuthy for providing the facilities needed for the study. The authors express their gratitude to Kerala Agricultural University, Thrissur, Kerala for providing fund for this study.

\section{Competing I nterests} interests.

The authors declare that they have no competing

\section{References}

1. Wagstaff, J.D. (2008) International Poisonous Plants Checklist - An Evidence Based Reference. CRC Press, Taylor \& Francis Group, Florida, USA. p161.

2. Rajan, A., Nair, N.D., Valsala, K.V., Maryamma, K.I. and Ramachandran, K.M. (1986) Pathology of a nervous disorder in cattle caused by the toxicity of leaves of the tree Ficus tsiela Roxb. Indian Vet. J., 63: 184-186.

3. Nair, N.D., Abraham, M.J., Valsala, K.V., Nair, M.G. and Rajan, A. (1987) Clinico-patho logical features of experimental chela leaf poisoning in calves. Kerala J. Vet. Sci., 18: 84-90.

4. Satdive, R.K., Chimata, R., Namdeo, A. and Fulzele, D.P. (2012) In vitro screening for phytochemical and antimicrobial activity of poisonous plant Ficus tsiela Roxb. Int. J. Pharm. BioSci., 3(2): 213-221.

5. Chanda, S.K. and Bhaid, M.U. (1987) Studies on the digestibility and nutritive value of common dried fodder tree leaves of M.P. on goats: 4. Hay of phephar tree leaves (Ficus tsiela Roxb). Livest. Advis., 12: 5-8.

6. Ratnasooriya, W.D., Premakumar, G.A.S. and Tillekeratne, L.M.V. (1992) Exploratory behaviour of male rats treated with a crude extract of Ficus tsiela leaves. Med. Sci. Res., 20: 233-234.

7. Harborne, J.B. (1991) Phytochemical Methods - Guide to Modern Techniques of Plant Analysis. $2^{\text {nd }}$ ed. Chapman and Hall, India.

8. Pal, G.K. and Pal, P. (2001) Estimation of hemoglobin concentration. In: Textbook of Practical Physiology. $2^{\text {nd }}$ ed. Orient Longman, Chennai. p13-15.

9. Weiss, D.J. and Wardrop, K.J. editors. (2010) Schalm's Veterinary Hematology. $6^{\text {th }}$ ed. Blackwell Publishing, USA.

10. Moron, M.S., Depierre, J.W. and Mannervik, B. (1979) Levels of glutathione, glutathione reductase and glutathione s-transferase activities in rat lung and liver. Biochem. Biophys. Acta., 582: 67-78.

11. Fraga, C.G., Leibovitz, B.E. and Toppel, A.L. (1988) Lipid peroxidation measured as TBARS in tissue slices. Characterization and comparison with homogenates and microsomes. Free Radic. Biol. Med., 4: 155.

12. Snedecor, G.W. and Cochran, W.G. (1994) Statistical Methods. $8^{\text {th }}$ ed. The Iowa State University Press, USA.

13. Bafor, E.E. and Lgbinuwen, O. (2009) Acute toxicity studies of the leaf extract of Ficus exasperate on hematological parameters, body weight and body temperature. J. Ethnopharmacol., 123: 302-307.

14. Nair, N.D. (1999) Prevalence and pathology of polioencephalomalacia in goats (Ph.D. Thesis). Kerala Agricultural University, Thrissur, India.

15. Kaneko, J.J., Harvey, J.W. and Bruss, M.L. (2008) Clinical Biochemistry of Domestic Animals. $6^{\text {th }}$ ed. Academic Press, California, USA.

16. McGregor, A.H., More, L.J. and Harrison, D.J. (2003) Liver death and regeneration in parecetamol toxicity. Hum. Exp. Toxicol., 22: 223-227.

17. Alves, A.E., Ribeiro, A.P., Filippo, P.A., Apparicio, M.F., Motheo, T.F., Mostachio, G.Q., Vicente, W.R. and Moore, H.A. (2009) Evaluation of creatine kinase (CK) and aspartate aminotransferase (AST) activities after laparoscopic or conventional ovariectomy in queens. Schweiz. Arch. Tierheilkd., 151(5): 223-227.

18. Chatterjea, M.N. and Shinde, R., editors. (2002) Serum enzymes in heart diseases. In: Textbook of Medical Biochemistry. $5^{\text {th }}$ ed. Med Publication Ltd., New Delhi. p555-557.

19. Mandal, R.K. and Randhawa, S.N.S. (1999) Liver function test profile in lantana-induced hepatitis in buffalo calves (Bubalus bubalis). Indian J. Anim. Sci., 69: 320-321.

20. Gounalan, S., Somvanshi, R., Kumar, R., Dash, S. and Devi V. (1999) Clinico-pathological effects of bracken fern (Pteridium aquilinum) feeding in laboratory rats. Indian $J$. Anim. Sci., 69: 385-388.

21. Omer, A.E., Ayed, I.A.M. and El Badwi, S.M.A. (2013) Effect of gum arabic on nephrotoxicity induced by Aristolochia bracteata in Rats. Sch. Acad. J. Biosci., 1(7): 377-380.

22. Nair, N.D., Valsala, K.V., Ramachandran, K.M. and Rajan, A. (1985) Experimental studies on Chela leaf (Ficus tsiela Roxb) poisoning in calves. Kerala J. Vet. Sci., 16: 94-99.

23. Chaturvedi, P. and Segale, M. (2007) Effects of different types of water decoctions of fruit of Melia azedarach on glucose induced hyperglycemia, liver transaminase, lipid peroxidation and reduced glutathione in normal albino rats. Sci. Res. Essay, 9: 384-389.

24. Bharathan, M. and Joy, A.D. (2012) In vitro antioxidant activity of Boerrhavia diffusa. J. Vet. Anim. Sci., 43: 15-18.

25. Dorman, H.J., Kosa, M., Karlos, K., Hobn, Y. and Hittuner, R. (2003) Antioxidant properties and composition of aqueous extracts from Mentha sp., hybrids, varieties and cultivars. J. Agric. Food Chem., 51: 4563-4569.

26. Sood, S., Dawra, R.K., Sharma, O.P. and Kurude, N.P. (2003) Exposure to the fern Onychium contiguum causes increase in lipid peroxidation and alters antioxidant status in urinary bladder. Biochem. Biophys. Res. Commun., 302: 476-479.

27. Sarathchandra, G. and Balakrishnamurthy, P. (1997) Pertubations in glutathione and adenosine triphosphatase in acute oral toxicosis of Cleistanthus collinus: An indigenous toxic plant. Indian J. Pharm., 29: 82-85. 